\title{
Tourist Experience, Tourist Motivation and Destination Loyalty for Historic and Cultural Tourists
}

\author{
Juan Zhang ${ }^{1 *}$ and John Walsh ${ }^{2}$ \\ ${ }^{1}$ Fanli Business School, Nanyang Institute of Technology, Henan 473004, China \\ ${ }^{2}$ Department of Management, School of Business and Management, RMIT International University-Hanoi \\ Campus, Hanoi 100000, Viet Nam
}

\begin{abstract}
The main purpose of this study was to investigate the relationship between tourist experience, tourist motivation and destination loyalty for historic and cultural tourists. A survey of 1,389 tourists who visited Sheqi, an ancient town in center China was conducted as the basis for empirical analysis. The results of this study revealed that tourists' experience influenced destination loyalty positively, and tourist motivation mediated the effect of tourist experience on destination loyalty significantly.

Keywords: Destination loyalty, historic and cultural tourism, mediating effect, tourist experience, tourist motivation
\end{abstract}

ARTICLE INFO

Article history:

Received: 31 January 2020

Accepted: 19 June 2020

Published: 25 December 2020

DOI: https://doi.org/10.47836/pjssh.28.4.43

E-mail addresses:

Zhangjuan02331@163.com (Juan Zhang)

John.walsh2@rmit.edu.vn (John Walsh)

*Corresponding author

\section{INTRODUCTION}

Both academics and practitioners attach great importance to service quality in service marketing and the same is true for tourism. Insufficient attention has been given to another related factor, the experience of the service. Service experience involves the subjective personal feelings and reactions consumers have when they consume a service (Chen \& Chen, 2010). According to Pine and Gilmore (1999), besides 
consuming products and services, consumers seek unique and memorable experiences during their consumption process. So it is necessary for service providers to shift their mechanism from the "delivery-focused" service economy characterized by offering high service quality to "staged" experience economy that creates distinctive and memorable experiences (Oh et al., 2007). For tourism services, most tourists travel because they want to enjoy experiences that are different from their daily life, so it is particularly important to pay more attention to the experiences that tourists can enjoy. A better understanding of tourist experiences may provide industry with a breakthrough opportunity needed to cause practitioners to perform better.

Historic and cultural tourism is a special area of tourism which has become more and more popular (Chen \& Chen, 2010). In China, there are a lot of ancient cities and villages which have abundant historic and cultural tourism resources. Local government departments of these historic places develop historic and cultural tourism sites by making use of these historic resources to create employment opportunities and prompt the transformation and upgrading of the local economic structure. The revitalization of historic places led by tourism has driven the boom in historic and cultural tourism across China. After rapid development over several years, an apparent trend in historic and cultural tourism in China has emerged which is consistent with the general global trend. Most historic attractions have changed from being product-centered sites that focus on exhibitions and exposition, to visitor-centered sites that highlight tourist experiences (Apostolakis \& Jaffry, 2005). Since tourism, especially historic and cultural tourism, is basically a form of experiential consumption, the visitorcentered or experience-centered thinking provides the historic attractions with new approaches to differentiating themselves in an ever fiercercompetitive environment.

Although experience has played an important role in tourism, research on such experience has not been investigated in great depth. Most previous studies on tourist experience were focused on definitions of the tourism experience (Larsen, 2007; Palmer, 2005; Trauer \& Ryan, 2005), dimensions of tourism experience (Uriely et al., 2002; White \& White, 2004) and conceptual models of the tourism experience (Cohen, 2004; Cutler \& Carmichael, 2010; O’Dell, 2007). Research on the experiences of specific tourism experiences at historic and cultural sites is very limited. In China, the issue of tourist experience has not been addressed at all from the perspective of historic cultural tourism. Most studies regarding Chinese historic cultural destination management have focused on preservation and tourism development (Cheng, 2017), tourism industry market development (Tong, 2017), tourism planning and development (He \& Li, 2019) and evaluation of the tourism environment (Feng et al., 2013) of historic sites. The few studies in relation to tourist behaviour 
have centered on tourist expectations, service quality, perceived value and tourist satisfaction (Wang \& Mei, 2006; Wang et al., 2009). It has been shown that a good tourist experience has a positive impact on destination loyalty (Lee et al., 2007). As a big country with an ancient civilization and long history, China has numerous historic cultural attractions. There are, for example, 291 historic cultural cities and 1,253 historic cultural towns and villages registered as of 2018. To increase visitors' destination loyalty, historic and cultural attraction administration should emphasize providing high quality, desirable experiences that can add the perception of value to visitors followed by relevant research on tourist experiences in this sector. As such, the main objective of this study was to explore the service experience of historic cultural tourists in China and the relationship between tourist experience, intermediary construct and positive behavioural intention, i.e. destination loyalty. Insight into these relationships will help historic cultural attraction managers better understand visitors and satisfy their needs in a more favourable way.

The body of this article consists of five parts. Part 1 introduces the background, necessity and main purpose of this research and is followed by the literature review, which investigates past research concerning the main variables, namely, tourist experience, tourist motivation and destination loyalty and illustrates the gap in knowledge to be interrogated by the research. Part 3 involves a description of the materials and research methods of this study. The results are presented in part 4 . In part 5, the discussion and contribution to knowledge, as well as research limitations and future research suggestions are provided.

\section{LITERATURE REVIEW}

\section{Tourist Experience}

Tourist experience had become an important research issue in the 1960s and grew to be popular in the social science literature by the 1970s (Quan \& Wang, 2004). However, at that time tourist experience was discussed fragmentarily. After the 1990s, systematic research approaches, from qualitative studies to quantitative studies, were used to study tourist experience (Andereck et al., 2006).

In tourism research, experiences are viewed as the totality of the emotional, physical, spiritual and intellectual state of being when a person interacts with an event or special place (Noy, 2007; Pine \& Gilmore, 1999). This is a complex psychological process that is distinct from everyday experiences (Cohen, 2004). While defining tourist experience, both on-site experiences and past travel experiences are proposed and emphasized. On-site experience is defined as the interaction between tourists and attractions during the visiting process (Stamboulis \& Skayannis, 2003). Past travel experience is defined as an event special enough that it can form a long-term memory for the tourists 
(Larsen, 2007). O’Dell (2007) argued that tourist experience engaged not only the tourist but also the tourism industries that participated in the process of generation, staging and consumption of experience.

Though there are various definitions of the tourist experience, researchers had the common opinion that tourist experience was a subjective and personal concept (Li, 2000). Consequently, it can only be explained and understood by considering the specific individuals involved and the specific environment whence experiences derived (Jennings, 2006). Most of these definitions focus on the experiences on site, however, tourist experiences usually began before the visitation and developed throughout the visitation process and lasted after the trip in the form of the memory and communication of the events experienced (Clawson \& Knetsch, 1966).

\section{Motivation}

Motivation is defined as psychological/ biological needs and wants which arouse, direct, and integrate a person's behaviour and activity (Uysal \& Hagan, 1993). Tourist motivation is the intrinsic power that directly promotes people's tourism behavior (Wang \& Mei, 2006). In tourism research, tourists' motivations can be classified into two categories, namely push forces and pull forces (Dann, 1981). Push forces indicates the inner desires that cause people to travel, such as escaping reality, relaxation, exercising, adventure and exploration. Meanwhile, pull forces refer to the attributes of the tourism destination which attract the tourists, for example, natural scenery, leisure facilities, cultural atmosphere, events and catering (Crompton, 1979). Past research had shown that tourist motivation was related to tourist satisfaction (Yoon \& Uysal, 2005) and tourist behaviour (Gitelson \& Crompton, 1984).

\section{Destination Loyalty}

Since customer loyalty was proposed as a concept by Copeland in 1923, there have been more than 200 definitions of customer loyalty. There are basically three categories of opinions in this regard. The first category of opinion on customer loyalty is behavioural loyalty as described by Jacoby and Chestnut (1978), who explained customer loyalty from the perspective of repeated purchasing. In their opinion, customer loyalty was measured by customers' degree of patronage, sequence of purchase and probability of purchase. The second typical opinion about customer loyalty concerns attitudinal loyalty (Ajzen \& Fishbein, 1977). Positive emotional attitude was believed to be an indicator of positive behavioural intention for product or service and was seen as customer loyalty. The integration of behavioural and attitudinal loyalty is the third opinion. Dick and Basu (1994) argued that true customer loyalty should be considered the repeated purchasing action with relatively high attitudinal tendency.

In the past three decades, the concept of customer loyalty has been incorporated into the tourism context (Jang \& Feng, 2007; Mazanec, 2000). Consistent with the 
research studies in other sectors of service marketing, some researchers suggested that tourist loyalty was also bi-dimensional and comprised both attitudinal preference and behavioural revisit intention (Wang et al., 2009). The product in tourism is unique, tourists' motivations are complicated and tourism activities are influenced by time, distance and other objective factors. As a result, destination loyalty cannot be restricted to repeated visits only (Oppemann, 2000; Postma \& Jenkins, 1997).

\section{Relationships Between Variables}

Undoubtedly, tourist experience, tourist motivation and destination loyalty are of great importance for historic cultural destinations. However, studies exploring the relationships between these variables are rare. In previous research, perceived quality, motivation and satisfaction were defined as the major antecedents affecting destination loyalty (Wang \& Mei, 2006). However, in the tourism context, especially for historic cultural destinations, the concept of tourist experience is suggested to be more appropriate than perceived quality as a predictor of tourists' behavioural intentions (Chen \& Chen, 2010). Kao et al. (2008) found that experiential quality had a positive relationship with tourist satisfaction, which affected visitors' behavioural intentions positively in a theme park study. Some other studies on nature parks and urban tours also found that tourist experience influenced tourist behavioral tendency positively directly and indirectly (Chen, 2015; Zhou, 2016). Although the impact of tourist experiences on loyalty for historic cultural destinations has been demonstrated, there are few research studies regarding tourist motivation for historic cultural destinations. Tourist motivation has been empirically demonstrated to have a positive influence on destination loyalty (Wang \& Mei, 2006; Yoon \& Uysal, 2005), which leads to the question, what is the relationship between tourist experience and motivation for historic cultural tourists? Further, what is the mechanism underlying the relationships between tourist experience, tourist motivation and destination loyalty for historic cultural attracts? This study tries to cast some light on this question. It seems reasonable that the motivation for particular visits may come from previous tourism experience. Thus, it was assumed in this study that tourist motivation would play a mediating role in the relationship between tourist experience and destination loyalty.

Based on past studies, the relationships between variables were proposed (Figure 1) and four hypotheses were put forward, as follows:

1. H1 - Tourist experience influences destination loyalty significantly.

2. H2 - Tourist experience has a significant effect on tourist motivation.

3. H3 - Tourist motivation has a significant effect on destination loyalty.

4. H4 - Tourist motivation plays a mediating role in the association between tourist experience and destination loyalty. 


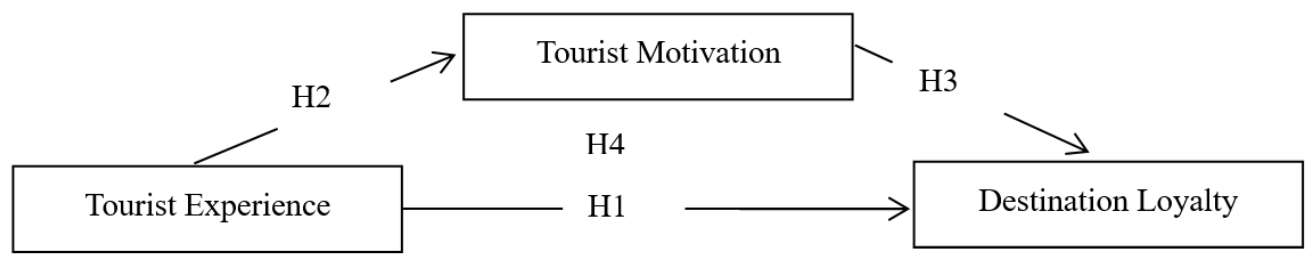

Figure 1. Proposed hypothetical model

\section{MATERIALS AND METHODS}

\section{Questionnaire Design and Operationalization of Constructs}

The three variables in this study are latent variables that cannot be measured directly; hence, observed variables were used in the questionnaire. The survey instrument was based on a thorough literature review and in-depth interviews with experts familiar with the peculiarities of the destination were also taken into account. The questionnaire consisted of two parts. Part A contained three sets of questions to measure tourists' experience, motivation and destination loyalty with a total of 27 items. A five-point Likert-type scale was used as the response format. Part B consisted of 11 questions reflecting the respondents' demographic characteristics and travel behaviour.

\section{Operationalization of Tourist Experience.}

There are no uniform measurements for the tourist experience. In the past, there had only been a few empirical research studies about tourist experience and the construct was measured in different ways. Wang and Mei (2006) used perceived quality of services received by tourists as the measurement of tourist experience. Otto and Ritchie (1996) developed a four-factor experience scale, consisting of hedonics, peace of mind, involvement and recognition. From a different point of view, Kao et al. (2008) suggested four different dimensions of tourist experience, i.e. immersion, surprise, participation and fun.

Based on Pine and Gilmore's (2011) four realms of experience, Oh et al. (2007) developed a questionnaire to measure tourist experience and used variables following Churchill's (1979) procedure for developing a measurement scale. The experience scales were proven empirically reliable and valid (Oh et al., 2007). The scenario of their research was similar to this study and, therefore, this study has adopted the measurement scale of tourist experience with minimal changes to reflect the specific offerings and circumstances of the specific destination.

There were four main sections to identify the dimensions of the tourists' experience of the attraction; namely, education, aesthetics, entertainment and escapism. Each dimension has four items (see Table 1). Respondents were required to determine the degree to which each statement reflects their 
experience of visiting the ancient town along a five-point scale $(1=$ strongly disagree and $5=$ strongly agree).

The total Cronbach $\alpha$ for the measurement was 0.963 , which indicated good internal consistency of the construct.

Operationalization of Motivation. From the perspective of an anthropologist, tourists travel to escape the routine of daily life and seek authentic experiences (Yoon \& Uysal, 2005). From a socio-psychological point of view, tourist motivation involves seeking and avoidance dimensions (IsoAhola, 1982). Several studies have used push forces such as the desire for escape, health and fitness, rest and relaxation, family togetherness and adventure, as well as pull forces such as cultural attractions, beaches, recreation facilities, entertainment, natural scenery, parks and shopping, to measure tourist motivation (Pyo et al., 1989; Yuan $\&$ McDonald, 1990). Based on these studies and considering also the reality of the research object and the results of interviews with some tourists of historical and cultural attractions, eight items including both push and pull forces were utilised to measure tourist motivation (see Table 1) All items used a five-point Likert-type scale ranging from $1=$ not important at all to $5=$ very important. The total Cronbach $\alpha$ for the measurement was 0.900 , which indicated good internal consistency of the construct.

\section{Operationalization of Destination Loyalty.}

Many research studies viewed tourist loyalty as bi-dimensional, including both attitudinal commitment and behavioural revisit intention (Bigné et al., 2001; Hui et al., 2007). Revisit intentions and willingness to make recommendations have been shown to be reasonable measures of tourist loyalty (Wang \& Mei, 2006). With the rapid spread of social media applications, more and more tourists have tended to share and find tourism information online and so word of mouth has played an ever more important role in the tourism industry. Consequently, three items, namely "Revisit," "Make positive word-of-mouth" and "Recommend it to others" were used to measure destination loyalty. Respondents were asked to evaluate these items along a five-point scale ( $1=$ strongly disagree and $5=$ strongly agree).

The total Cronbach $\alpha$ for the measurement was 0.943 , which indicated good internal consistency of the construct.

Table 1

Measurement of the constructs

\begin{tabular}{ll}
\hline Constructs and Factors & Items \\
\hline Experience & \\
Education (ED) & The experience has made me more knowledgeable \\
& I learned a lot \\
\hline
\end{tabular}


Table 1 (Continued)

\begin{tabular}{ll}
\hline Constructs and Factors & Items \\
\hline & It stimulated my curiosity to learn new things \\
& It was a real learning experience \\
& I felt a real sense of harmony \\
& Just being here was very pleasant \\
& The setting really showed attention to design details \\
& The setting was very attractive \\
& It's interesting to visit here \\
& It's boring to visit here \\
& It's enjoyable to visit here \\
Entertainment (EN) & It's fun to visit here \\
& I felt I played a different character here \\
& I felt like I was living in a different time or place \\
& I completely escaped from reality \\
& I totally forgot about my daily routine \\
Escapism (EC) & I visit here to broaden my knowledge \\
Mull (PL) & I visit here to relax \\
I visit here to escape from daily routine & I visit here to visit relatives and friends \\
I visit here to seek cultural identity \\
I visit here to appreciate original and authentic ancient \\
buildings and surroundings \\
I visit here to enjoy the beautiful scenery \\
I visit here to taste special delicious foods \\
I will revisit here later \\
I will make positive word-of-mouth \\
I will recommend it to others \\
\hline
\end{tabular}




\section{Sample Design and Data Collection}

The questionnaire survey was conducted during May 2019 at an ancient town, namely Sheqi, a historic and cultural site located in central China. Since central China is the cradle of Chinese civilization and has abundant historic cultural tourism resources and Sheqi is a typical historic attraction with a well-documented history and valuable, well preserved heritage and cultural relics and has shown its ability to be sustainable over a long period of time. Although Sheqi has valuable heritage, it is not famous in China owing to inconvenient transportation and less developed tourism infrastructure. Only tourists from Henan province and a few nearby provinces have visited Sheqi ancient town. So the survey targeted Chinese tourists visiting the ancient town with a questionnaire in Chinese language. A convenience sampling method was adopted because of limited time and manpower. After a short training session concerning questionnaire survey skills given by the principal researcher, some experienced tour guides were asked to help distribute the questionnaires to different groups of tourists. The questionnaire was distributed at the exit and the service centre of the attraction. Visitors who had completed their visits were asked about their willingness to participate in the questionnaire survey. If they were willing, they were asked to complete the questionnaire either on paper or on the cellphone by scanning the QR code. Since structural equation modeling (SEM) would be used to test the hypotheses later, according to the sampling principle of SEM and the average number of tourists visiting the ancient town, i.e. 30,000 visitors per month, a total of 1,500 questionnaires was distributed and 1,389 usable responses were obtained with 111 unacceptable questionnaires removed. The response rate was $92.6 \%$.

\section{Data Analysis Methods}

In most applied research, Baron and Kenny's (1986) causal steps approach has been used to test mediating effects. In recent years, however, many researchers of methodology (Edwards \& Lambert, 2007; Zhao et al., 2010) questioned the rationality of the causal steps approach. Subsequently, the bootstrap method has been adopted as a more effective approach to testing mediating effects (Wen \& Ye, 2014). Consequently, the Bootstrap method has been used to test the significance of the mediating effect in this study.

The data collected were normally distributed according to the normal test and confirmatory factor analysis was conducted to test the validity of the measurement model. Pearson product-moment correlation analysis was performed to explore the associations between destination loyalty, tourist experience and tourist motivation. The Bootstrap method was used to test the significance of the mediating effect. Furthermore, SEM among latent variables was established to verify further the mediating effect with Mplus7.0 statistical software. 


\section{RESULTS AND DISCUSSION}

The results of this study found that there were slightly more female visitors $(51.6 \%)$ than male. The majority of respondents were aged between 18 and 49 (91.6\%), originating from Nanyang district and other districts of Henan province $(70.8 \%$ ) and had at least three years of college education $(82.5 \%)$, with a monthly income of less than 5000 Yuan (72.5\%). Many respondents knew about the ancient town through recommendations by family and friends $(46.2 \%)$ and visited with friends and family members $(64.9 \%)$.

\section{Confirmatory Factor Analysis}

To test the discriminant validity of the three latent variables, namely destination loyalty, tourist experience and tourist motivation, confirmatory factor analysis was employed using Mplus 7.0 software. Considering that there were many measuring items corresponding to the variable of tourist experience, in order to improve the degree of fit of the model, the corresponding items of the latent variable of tourist experience were parceled to four observed entries ( $\mathrm{Wu}$ $\&$ Wen, 2011). The results of confirmatory factor analyses in Table 2 showed that, compared with the single- and two-factor models, the three-factor model had the best fit. It suggested that the three latent variables used in this study were highly discriminated and the validity of the survey instrument was more than acceptable.

Table 2

Confirmatory factor analysis results

\begin{tabular}{lllllll}
\hline Model & $\chi^{2}$ & df & $\chi^{2} / \mathrm{df}$ & CFI & TLI & RMSEA \\
\hline $\begin{array}{l}\text { Three-factor } \\
\text { model;DL;TE;TM }\end{array}$ & 342.716 & 87 & 3.939 & 0.941 & 0.929 & 0.077 \\
$\begin{array}{l}\text { Two-factor } \\
\text { model;DL+TM;TE }\end{array}$ & 3961.506 & 89 & 44.511 & 0.831 & 0.800 & 0.177 \\
$\begin{array}{l}\text { Two-factor } \\
\text { model;DL;TE+TM }\end{array}$ & 4320.872 & 89 & 48.549 & 0.815 & 0.782 & 0.185 \\
$\begin{array}{l}\text { Single factor } \\
\text { model;DL+TE+TM }\end{array}$ & 5320.867 & 90 & 59.121 & 0.772 & 0.733 & 0.205 \\
\hline
\end{tabular}

Note: DL means destination loyalty; TE means tourist experience; TM means tourist motivation 


\section{Common Method Deviation Test}

All data of the research were collected from the questionnaires filled in by tourists independently, and the same-origin data may affect the reliability of the research conclusion. Harman's single-factor test was employed to assess the likelihood of influence of common method variance by entering 27 observed variables to the unrotated factor analysis (Podsakoff \& Organ, 1986). The results showed that the eigenvalues of the three factors were greater than 1 , and the variance explained by the first principle component was $18.322 \%$, much lower than the critical value of $40 \%$, indicating that there is no obvious deviation of common method which will not influence the reliability of the results.

\section{Descriptive Statistics and Correlation Analyses}

The mean, standard deviation, and correlation coefficient of latent variables were statistically analyzed using SPSS 24.0. As shown in Table 3, the mean and standard deviation of each variable were within the acceptable range. According to the correlation coefficient between variables, a significant correlation exists between destination loyalty, tourist experience, and tourist motivation. Tourist experience was positively correlated with destination loyalty $(\mathrm{r}=0.839, \mathrm{P}<0.01)$, tourist motivation and destination loyalty had positive relationship ( $\mathrm{r}=0.694, \mathrm{P}<0.01$ ), and tourist experience and tourist motivation also related to each other positively $(r=0.751, \mathrm{P}<0.01)$. The results of related analysis preliminarily illustrate the relationship between variables assumed, providing a basis for further data analysis.

Table 3

Means, standard deviation, and correlation efficient for variables $(N=1389)$

\begin{tabular}{lllllll}
\hline Variable & 1 & 2 & 3 & 4 & 5 & 6 \\
\hline Gender & - & & & & & \\
Education level & $-0.068^{*}$ & - & & & & \\
Monthly income & $-0.181^{* *}$ & $0.369^{* *}$ & - & & & \\
DL & 0.005 & 0.014 & -0.033 & - & & \\
TE & 0.014 & -0.033 & $-0.084^{* *}$ & $0.839^{* *}$ & - & \\
TM & 0.020 & 0.031 & -0.022 & $0.694^{* *}$ & $0.751^{* *}$ & - \\
Mean & 1.620 & 3.010 & 1.590 & 4.061 & 3.971 & 3.773 \\
S.D. & 0.486 & 0.887 & 1.069 & 0.88835 & 0.87733 & 0.88314 \\
\hline
\end{tabular}




\section{Hypotheses Testing}

Model 14 of the macro-program of PROCESS in SPSS software was employed to test the mediating effect of the relationship between tourist experience and destination loyalty under the control of gender, education level and monthly income. The results (see Table 4 and Table 5) showed that the positive prediction effect of tourist experience on destination loyalty was significant $(\beta=0.853, p<0.01)$ and the direct prediction effect of tourist experience on destination loyalty was still significant when the mediating variable was included $(\beta=0.746, \mathrm{p}<0.01)$, which indicated that $\mathrm{H} 1$ was verified. It also could be seen that tourist experience had a significant positive predictive effect on tourist motivation $(\beta=0.758, p<0.01)$ and tourist motivation had a significant positive predictive effect on destination loyalty ( $\beta=0.141, \mathrm{p}<0.01)$, which suggested that both $\mathrm{H} 2$ and $\mathrm{H} 3$ were supported. Furthermore, the lower and upper bootstrap $95 \%$ confidence interval of the direct effect of tourist experience on destination loyalty $(0.703 \sim 0.789)$ and the mediating effect of tourist motivation $(0.064 \sim 0.151)$ all excluded 0 (Table 5), thereby indicating that tourist experience could predict destination loyalty both directly through the main effect and indirectly through the mediating effect of tourist motivation. The main effect (0.746) and mediating effect $(0.107)$ accounted for $87.46 \%$ and $12.54 \%$ of the total effect (0.853) respectively. Consequently, H4 was also verified.

Table 4

Mediating effect of tourist motivation

\begin{tabular}{lllllll}
\hline Viable & \multicolumn{3}{c}{ DL } & \multicolumn{3}{c}{ TM } \\
\cline { 2 - 7 } & $\beta$ & SE & $\mathrm{t}$ & $\beta$ & $\mathrm{SE}$ & $\mathrm{t}$ \\
\hline Constant & 0.538 & 0.089 & 6.015 & 0.535 & 0.108 & $4.940^{* *}$ \\
Gender & 0.002 & 0.027 & 0.063 & 0.033 & 0.033 & 1.004 \\
Education level & 0.032 & 0.016 & $2.066^{*}$ & 0.046 & 0.019 & $2.439^{*}$ \\
Monthly income & 0.022 & 0.013 & 1.643 & 0.022 & 0.016 & 1.396 \\
TE & 0.853 & 0.015 & $57.653^{* *}$ & 0.758 & 0.018 & $42.359^{* *}$ \\
TM & - & - & - & - & - & - \\
R-square & \multicolumn{3}{c}{0.841} & & & \multicolumn{3}{c}{0.752} & \\
F & $833.212^{* *}$ & & & & & \\
\hline
\end{tabular}


Table 4 (Continued)

\begin{tabular}{llll}
\hline Viable & \multicolumn{3}{c}{$\mathrm{DL}$} \\
\cline { 2 - 4 } & $\beta$ & $\mathrm{SE}$ & $\mathrm{t}$ \\
\hline Constant & 0.463 & 0.089 & $5.203^{* *}$ \\
Gender & -0.003 & 0.027 & -0.109 \\
Education level & 0.026 & 0.016 & 1.672 \\
Monthly income & 0.019 & 0.013 & 1.420 \\
TE & 0.746 & 0.022 & $33.772^{* *}$ \\
TM & 0.141 & 0.022 & $6.418^{* *}$ \\
R-square & \multicolumn{2}{c}{0.8456} \\
F & \multicolumn{3}{c}{$694.159^{* * *}$} \\
\hline
\end{tabular}

Table 5

Total effect, main effect and the mediating effect

\begin{tabular}{lllll}
\hline Effect & Value of effect & S.D. & $\begin{array}{l}\text { Bootstrap 95\% } \\
\text { confidence } \\
\text { interval }\end{array}$ & Relative effect \\
\hline $\begin{array}{l}\text { Total effect } \\
\text { Direct effect }\end{array}$ & 0.853 & 0.015 & $0.824 \sim 0.882$ & - \\
$\begin{array}{l}\text { Intermediary } \\
\text { effect }\end{array}$ & 0.107 & 0.022 & $0.703 \sim 0.789$ & $87.46 \%$ \\
\hline
\end{tabular}

To measure further the relationship between tourist experience, tourist motivation and destination loyalty comprehensively and accurately, as well as eliminate the interference of measurement errors on the research results, Mplus7.0 was used to re-test the hypothesis model (Figure 2) (Fang \& Wen, 2018). Considering that there were many measuring items corresponding to the variable of tourist experience and to improve the degree of fit of the model, the corresponding items of the latent variable of tourist experience were parceled in four observed entries, based on which the hypothesis model was developed. The results indicated that the model fitting was acceptable $\left(\chi^{2} / \mathrm{df}=3.973, \mathrm{CFI}=0.941\right.$, $\mathrm{TLI}=0.929, \mathrm{RMSEA}=0.077, \mathrm{SRMR}=$ 0.038). 
Juan Zhang and John Walsh

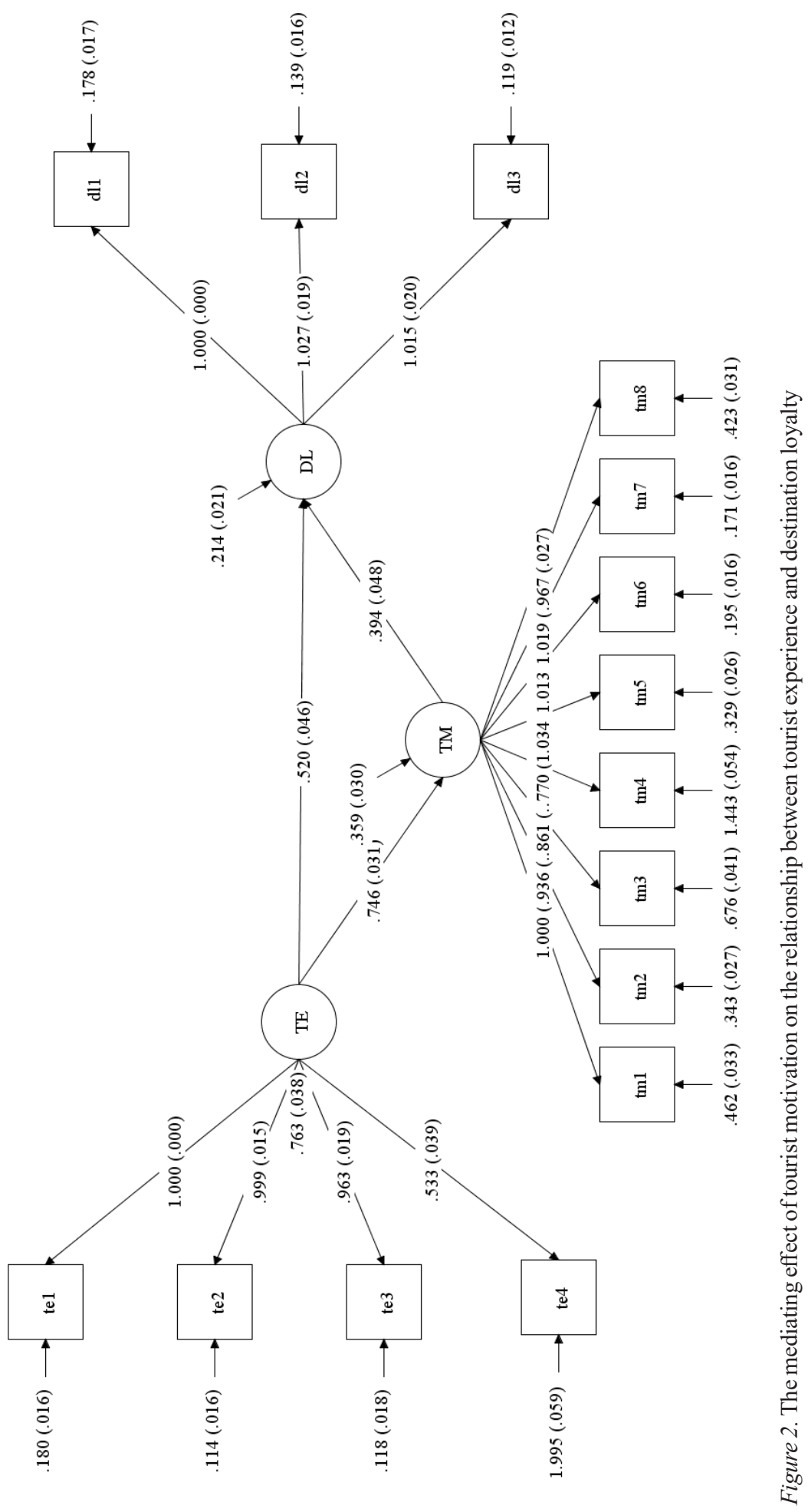




\section{CONCLUSION}

\section{Contribution to Knowledge}

The empirical results of this study proved that the proposed hypothetical model designed to consider tourist experience, tourist motivation and destination loyalty simultaneously for historic cultural destinations in China was acceptable, thereby filling this gap in the literature. In past studies, researchers attached great importance to the individual construct and other variables influencing destination loyalty such as perception of quality, expectation, destination image, perception of value and tourist satisfaction (Wang et al., 2009; Yoon \& Uysal, 2005). However, there has been a lack of focus on the construct of tourist experience, especially in terms of conceptual models and empirical studies pertaining to causal relationships among tourist experience, tourist loyalty and other constructs.'

Furthermore, this study provided empirical evidence that tourist experience had a positive effect on tourist motivation. Previous studies examine the construct of motivation as an antecedent of travel satisfaction (Wang et al., 2009; Yoon \& Uysal, 2005). However, no research concerning variables that affect tourist motivation has been done so far as is known. Meanwhile, it was demonstrated in this study that tourist motivation had a significant impact on destination loyalty of historic cultural tourists, which was in line with the findings of Yoon \& Uysal (2005).

The mediating effect of tourist motivation in the relationship between tourist experience and loyalty was verified in this study, which provided a detailed explanation of the effecting mechanism of tourist experience on destination loyalty.

This study fills the theoretical gaps both in tourist experience research for Chinese historic cultural destinations and in relationships between tourist experience and tourist motivation. It was believed that this study had the capability of developing more precise studies and applications of tourism behavior, especially concerning the tourist experience, tourist motivation and destination loyalty.

\section{Managerial Implications}

The findings of this has managerial implications for the success of the marketing of Sheqi ancient town and other historic cultural destinations. With the rapid development of historic tourism in China in recent years, competition among historic destinations has become increasingly fierce. In China, there are more than 2,000 ancient towns which have developed or are developing historic tourism. However, the number of ancient towns that tourists can name is less than ten. Since so many ancient towns have marketed themselves in a similar way, they end up promoting similar buildings, activities and commodities. The results in tourist fatigue and lack of destination loyalty. As shown empirically in this study, if tourists obtain unique and memorable experiences about a specific destination, they will be willing to revisit it, make positive word-of-mouth about it and recommend it to other people. So, it is 
worthwhile for historic cultural destinations to make significant investments in their destinations to enhance tourists' experiences and improve their loyalty towards the destination. Besides, this study found that tourist motivation mediated the effect of tourist experience on destination loyalty, which indicated that historic destination managers should give attention to tourists' motivation for travelling. As shown in Figure 2, for the specific destination in this study, i.e. Sheqi ancient town, the tourists' motivation to broaden knowledge, relax, seek cultural identity and appreciate original and authentic ancient buildings and surroundings should be stressed by the destination manager so as to enhance tourists' experience and increase the attractiveness of the destination.

Finally, the findings of this study also indicate that destination loyalty did not manifest only as revisit intention. Owing to the economic conditions of the family, diversity of travel motivation and limitation of travelling time, satisfactory tourist experiences alone could not ensure their revisit to a specific destination. However, they were willing to make recommendations and provide positive word-of-mouth, which could be seen as another aspect of destination loyalty. From this perspective, destination managers should comprehend destination loyalty from the twin dimensions of behavioural loyalty and attitudinal loyalty. On the one hand, measures should be taken to encourage tourists to revisit the destination while, on the other hand, diverse platforms, such as social media platforms, should be provided for tourists to provide positive word-of-mouth publicity and recommendations.

Although this research was conducted in one particular ancient town, Sheqi, the managerial implications for enhancing tourists' experiences and taking advantage of diverse platforms to facilitate positive word-of-mouth could be adopted by other historic cultural attractions to improve their marketing performances.

\section{Policy Implications}

The findings of this study also have some policy implications for the Chinese tourism industry. In 1982, 1986 and 1994, the Chinese State Council identified three batches of famous national historic cultural cities followed by subsequent supplementary batches. In total, there have been more than 2,000 famous Chinese historic cultural cities, town and villages registered in different areas of China as of the end of 2018. Now they are being used to encourage the development of the economy and society by developing the tourism industry in China and many historic cultural destinations are jumping on the tourism bandwagon. However, many historic cultural destinations have made use of homogenous approaches and lack distinctive attractiveness. This research found that the tourist experience played a very important role in tourist behaviour regarding its relations with tourist motivation and destination loyalty. Consequently, the policy makers should guide historic cultural destinations to build their own unique image and develop special 
tourism projects based on their personal resources and characteristics so as to enhance the tourist experience. Moreover, professional tourism talent training programs should be launched to improve the qualities, skills and performances of tourism practitioners. Tourism policies should lead Chinese tourism industry development in a healthy environment and a highly professional way to transcend the low level homogeneous competition currently found. From this perspective, these findings could benefit other ancient cultural attractions across China.

\section{Limitations and Future Research}

In terms of the sample obtained, owing to the limitations of the research site, only tourists visiting the small ancient town of Sheqi were surveyed and most of the respondents came from the same province, which might not reflect the general conditions of destination loyalty to historic cultural attractions in China overall. Future studies may consider different historic cultural attractions such as Zhuxian ancient town, Shenhou ancient town, Jingziguan ancient town, Tiemen ancient town and Huimeng ancient town in central China, Zhouzhuang, Luzhi in eastern China and Pingyao and Luodai in western of China, for greater generalization. Secondly, destination loyalty was proven to be influenced by diverse variables (Wang \& Mei, 2006) and this study focused on the impact of tourist experience and tourist motivation on destination loyalty for a historic cultural attraction. In the future, the tourist experience can be integrated into a more comprehensive destination loyalty model involving more variables, such as destination image, tourist expectation, perceived value and tourist satisfaction. This would further enrich the research model and conclusions by developing a more comprehensive tourist satisfaction model for historic cultural attractions and providing innovative approaches to upgrade the tourism industry in historic cultural destinations.

\section{ACKNOWLEDGEMENT}

The authors gratefully acknowledge the support of anonymous peer reviewers and the editor in making the publishing of this paper possible.

\section{REFERENCES}

Ajzen, I., \& Fishbein, M. (1977). Attitude-Behavior relations: A theoretical analysis and review of empirical study. Psychological Bulletin, 84(5), 888-918. doi: 10.1037/0033-2909.84.5.888

Andereck, K., Bricker, K. S., Kerstetter, D., \& Nickerson, N. P. (2006). Connecting experiences to quality: Understanding the meanings behind visitors' experiences. In G. Jennings \& N. P. Nickerson (Eds.), Quality tourism experiences (pp. 81-98). Burlington, USA: Elsevier Butterworth-Heinemann. doi: 10.4324/9780080455778

Apostolakis, A., \& Jaffry, S. (2005). A choice modeling application for Greek heritage attractions. Journal of Travel Research, 43(3), 309-318. doi: $10.1177 / 0047287504272035$

Baron, R. M., \& Kenny, D. A. (1986). The moderator-mediator variable distinction in social psychological research: Conceptual, strategic, and statistical considerations. Journal 
of Personality and Social Psychology, 51, 11731182. doi: 10.1177/0047287504272035

Bigné, J., Sánchez, M., \& Sánchez, J. (2001). Tourism image, evaluation variables and after purchase behavior: Inter-relationships. Tourism Management, 22(6), 607-616. doi: 10.1016/ S0261-5177(01)00035-8

Chen, C. F., \& Chen, F. S. (2010). Experience quality, perceived value, satisfaction and behavioral intentions for heritage tourists. Tourism Management, 31(1), 29-35. doi: 10.1016/j. tourman.2009.02.008

Chen, W. (2015). Research on the relationship between tourist experience and its influencing factors as well as after travel behavior intention (Doctoral dissertation), Yunnan University, China.

Cheng, S. L. (2017). On the protection and path of Suzhou historic cultural tourism districts from the perspective of cultural and tourism integration. Journal of Commercial Economics, 12,135-137.

Churchill, G. (1979). A paradigm for developing better measures of marketing constructs. Journal of Marketing Research, 16(1), 64-73. doi: $10.2307 / 3150876$

Clawson, M., \& Knetsch, J. L. (1966). Economics of outdoor recreation. Baltimore, USA: Johns Hopkins Press.

Cohen, E. (2004). Contemporary tourism: Diversity and change. Oxford, England: Elsevier.

Crompton, J. L. (1979). Motivations for pleasure vacation. Annals of Tourism Research, 6(4), 408-424. doi: 10.1177/004728758001900185

Cutler, S. Q., \& Carmichael, B. (2010). The dimensions of the tourist experience. In M. Morgan, P. Lugosi \& B. Ritchie (Eds.), The tourism and leisure experience: Consumer and managerial perspectives (pp. 3-26). Bristol, England: Channel View Publications.

Dann, G. M. (1981). Tourist motivation an appraisal. Annals of Tourism Research, 8(2), 187-219. doi: 10.1016/0160-7383(81)90082-7

Dick, A., S., \& Basu, K. (1994). Customer loyalty: Toward an integrated conceptual framework. Journal of Academy of Marketing Science, 22, 99-113. doi: 10.1177/0092070394222001

Edwards, J. R., \& Lambert, L. S. (2007). Methods for integrating moderation and mediation: A general analytical framework using moderated path analysis. Psychological Methods, 12, 1-22. doi: 10.1037/1082-989X.12.1.1

Fang, J., \& Wen, Z. L. (2018). Analysis of moderated mediating effect based on structural equation model. Journal of Psychological Science, 41(02),453-458.

Feng, G. J., Yan, X. C., \& Jia, W. J. (2013). An empirical study on the quantitative evaluation of tourism resources in Langzhong ancient city, Sichuan province. Ecological Economy, 1, 332-335.

Gitelson, R. J., \& Crompton, J. L. (1984). Insights into the repeat vacation phenomenon. Annals of Tourism Research, 11(2), 199-217. doi: 10.1016/0160-7383(84)90070-7

He, S. Y., \& Li, F. (2019). Discussion on resource distribution and tourism development strategy of ancient villages in western Hunan province. Architecture \& Culture, 4, 234-235.

Hui, T. K., Wan, D., \& Ho, A. (2007). Tourists' satisfaction, recommendation and revisiting Singapore. Tourism Management, 28(4), 965975. doi: 10.1016/j.tourman.2006.08.008

Iso-Ahola, S. E. (1982). Toward a social psychological theory of tourism motivation: A rejoinder. Annals of Tourism Research, 9(2), 256-262. doi: 10.1016/0160-7383(82)90049-4 
Jacoby, J. W., \& Chestnut, R. W. (1978). Brand loyalty measurement and management. New York, USA: Wiley. doi: 10.1080/00913367.1979.10717981

Jang, S. C., \& Feng, R. M. (2007). Temporal destination revisit intention: The effects of novelty seeking and satisfaction. Tourism Management, 28(2), 580-590. doi:10.1016/j. tourman.2006.04.024

Jennings, G. (2006). Perspectives on quality tourism experiences: An introduction. In G. Jennings \& N. P. Nickerson (Eds.), Quality tourism experiences (pp. 1-22). Burlington, USA: Elsevier Butterworth-Heinemann. doi: $10.1080 / 19368620802594169$

Kao, Y. F., Huang, L. S., \& Wu, C. H. (2008). Effects of theatrical elements on experiential quality and loyalty intentions for theme parks. Asia Pacific Journal of Tourism Research, 13(2), 163-174. doi: 10.1080/10941660802048480

Larsen, S. (2007). Aspects of a psychology of the tourist experience. Scandinavian Journal of Hospitality and Tourism, 7(1), 7-18. doi: $10.1080 / 15022250701226014$

Lee, S. Y., Petrick, J. F., \& Crompton, J. (2007). The roles of quality and intermediary constructs in determining festival attendees' behavioral intention. Journal of Travel Research, 45(4), 402-412. doi: 10.1177/0047287507299566

Li, Y. (2000). Geographical consciousness and tourism experience. Annals of Tourism Research, 27(4), 863-883. doi: 10.1016/S0160-7383(99)00112-7

Mazanec, J. A. (2000). Introduction: Reports from the second symposium on the consumer psychology of tourism, hospitality and leisure (CPTHL). Tourism Analysis, 5, 64-68.

Noy, C. (2007). The poetics of tourist experience: An autoethnography of a family trip to Eilat. Journal of Tourism and Cultural Change, 5(3), 141-157. doi: $10.2167 /$ jtcc 085.0
O'Dell, T. (2007). Tourist experiences and academic junctures. Scandinavian Journal of Hospitality and Tourism, 7(1), 34-45. doi: 10.1080/15022250701224001

Oh, H., Fiore, A. M., \& Jeoung, M. (2007). Measuring experience economy concepts: Tourism applications. Journal of Travel Research, 46(2), 119-132. doi: 10.1177/0047287507304039

Oppemann, M. (2000). Tourism destination loyalty. Journal of Travel Research, 39(1), 78-84. doi: $10.1177 / 004728750003900110$

Otto, J. E., \& Ritchie, J. R. B. (1996). The service experience in tourism. Tourism Management, 17(3), 165-174. doi: 10.1016/02615177(96)00003-9

Palmer, C. (2005). An ethnography of Englishness: Experiencing identity through tourism. Annals of Tourism Research, 32(1), 7-27. doi: 10.1016/j. annals.2004.04.006

Pine, B. J., \& Gilmore, H. J. (1999). The experience economy: Work is theatre \& every business a stage. Boston, USA: Harvard Business School Press. doi: 10.4337/9781781004227.00007

Pine, B. J., \& Gilmore, J. (2011). The experience economy. Boston, USA: Harvard Business Review Press.

Podsakoff, P. M., \& Organ, D. W. (1986). Selfreports in organizational research: Problems and prospects. Journal of Management, 12(4), 531-544. doi: 10.1177/014920638601200408

Postma, A., \& Jenkins, A. K. (1997). Improving the tourist's experience: Quality management applied in tourist destinations. In P. E. Murphy (Ed.), Quality management in urban tourism, 183-197. Chichester, England: Wiley. doi: 10.1080/13032917.2012.696272 
Pyo, S., Mihalik, B. J., \& Uysal, M. (1989). Attraction attributes and motivations: A canonical correlation analysis. Annals of Tourism Research, 16(2), 277-282. doi: 10.1016/01607383(89)90077-7

Quan, S., \& Wang, N. (2004). Towards a structural model of the tourist experience: An illustration from food experiences in tourism. Tourism Management, 25, 297-305. doi: 10.1016/S02615177(03)00130-4

Stamboulis, Y., \& Skayannis, P. (2003). Innovation strategies and technology for experience-based tourism. Tourism Management, 24(1), 35-43. doi: 10.1016/S0261-5177(02)00047-X

Tong, J. (2017). Tourism development and ecological balance of the local society. Architecture \& Culture, 8, 171-172.

Trauer, B., \& Ryan, C. (2005). Destination image, romance and place experience--an application of intimacy theory in tourism. Tourism Management, 26(4), 481-491. doi: 10.1016/j. tourman.2004.02.014

Uriely, N., Yonay, Y., \& Simchai, D. (2002). Backpacking experiences: A type and form analysis. Annals of Tourism Research, 29(2), 520-538. doi: 10.1016/S0160-7383(01)00075-5

Uysal, M., \& Hagan, L. A. R. (1993). Motivation of pleasure travel and tourism. Encyclopedia of Hospitality and Tourism, 21, 798-810.

Wang, X., \& Mei, H. (2006). Tourist satisfaction of tourism destination: model and empirical study. Journal of Beijing International Studies University (Tourism Edition), (137), 58-62.
Wang, X., Zhang, J., Gu, C. L., \& Zhen, F. (2009). Examining antecedents and consequences of tourist satisfaction: A structural modeling approach. Tsinghua Science and Technology, 14(3), 397-406. doi: 10.1016/S10070214(09)70057-4

Wen, Z. L., \& Ye, B. J. (2014). Analyses of mediating effects: The development of methods and models. Advances In Psychological Science, 22(5), 731745. doi: 10.3724/SP.J.1042.2014.00731

White, N. R., \& White, P. B. (2004). Travel as transition: Identity and place. Annals of Tourism Research, 31(1), 200-218. doi: 10.1016/j. annals.2003.10.005

Wu, Y., \& Wen, Z. L. (2011). Item parceling strategies in structural equation modeling. Advances in Psychological Science, 19(12), 1859-1867.

Yoon, Y., \& Uysal, M. (2005). An examination of the effects of motivation and satisfaction on destination loyalty: A structural model. Tourism Management, 26(1), 45-56. doi: 10.1016/j. tourman.2003.08.016

Yuan, S., \& McDonald, C. (1990). Motivational determinates of international pleasure time. Journal of Travel Research, 29(1), 42-44. doi: 10.1177/004728759002900109

Zhao, X., Lynch Jr., J. G., \& Chen, Q. (2010). Reconsidering Baron and Kenny: Myths and truths about mediation analysis. Journal of Consumer Research, 37, 197-206. doi: $10.1086 / 651257$

Zhou, B. L. (2016). The relationships among emotional experience, satisfaction and behavioral intentions. Xi'an, China: Northwestern University. 